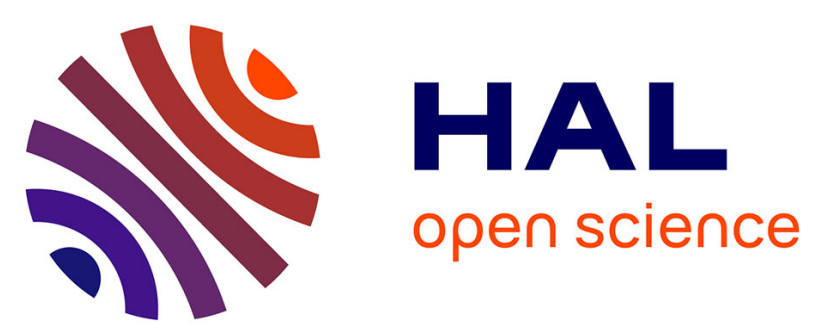

\title{
Pain rate and social circumstances rather than cumulative organ damage determine the quality of life in adults with sickle cell disease.
}

Charlotte Fj van Tuijn, Eduard J. Beers, Van, John-John B. Schnog, Bart J.

Biemond

\section{To cite this version:}

Charlotte Fj van Tuijn, Eduard J. Beers, Van, John-John B. Schnog, Bart J. Biemond. Pain rate and social circumstances rather than cumulative organ damage determine the quality of life in adults with sickle cell disease.. American Journal of Hematology, 2010, 85 (7), pp.532. 10.1002/ajh.21731. hal-00552326

\section{HAL Id: hal-00552326 \\ https://hal.science/hal-00552326}

Submitted on 6 Jan 2011

HAL is a multi-disciplinary open access archive for the deposit and dissemination of scientific research documents, whether they are published or not. The documents may come from teaching and research institutions in France or abroad, or from public or private research centers.
L'archive ouverte pluridisciplinaire HAL, est destinée au dépôt et à la diffusion de documents scientifiques de niveau recherche, publiés ou non, émanant des établissements d'enseignement et de recherche français ou étrangers, des laboratoires publics ou privés. 


\section{American Journal of Hematology}

WILEY

\section{Pain rate and social circumstances rather than cumulative organ damage determine the quality of life in adults with sickle cell disease.}

\begin{tabular}{|c|c|}
\hline Journal: & American Journal of Hematology \\
\hline Manuscript ID: & AJH-10-0105.R2 \\
\hline Wiley - Manuscript type: & Letters \\
\hline $\begin{array}{r}\text { Date Submitted by the } \\
\text { Author: }\end{array}$ & 06-Apr-2010 \\
\hline Complete List of Authors: & $\begin{array}{l}\text { van Tuijn, Charlotte; Academic Medical Center } \\
\text { Beers, van, Eduard; Academic Medical Centre, Hematology } \\
\text { Schnog, John-John; St. Elisabeth Hospital, Department of } \\
\text { Hematology and medical oncology } \\
\text { Biemond, Bart; Academic Medical Centre, Hematology }\end{array}$ \\
\hline Keywords: & $\begin{array}{l}\text { Sickle cell disease, Hemoglobinopathies, Quality of Life, } \\
\text { Psychosocial }\end{array}$ \\
\hline
\end{tabular}

\section{s ScholarONE" \\ Manuscript Central}


1 Due to the significant morbidity associated with sickle cell disease (SCD) sickle cell 2 patients have a reduced quality of life (QoL). Even though pain is considered an 3 important determinant of QoL in sickle cell patients, factors such as organ damage and socioeconomic circumstances may also be important. Therefore we determined the contribution of chronic organ damage and sickle cell related complications to QoL and also analysed the effect of vaso-occlusive crises and socio-economic circumstances on QoL. Consecutive adult sickle cell patients were included. QoL was represented in a physical component scale (PCS) and a mental component scale (MCS) and assessed with SF-36 forms. Higher pain rates were related to lower QoL scores. Both occupation and the level of education were significantly related to PCS while no relation with MCS or pain rate was found. Thirty-five percent patients were unemployed as compared to $6 \%$ of the general population and $16 \%$ of immigrants without SCD. Neither genotype nor the presence of chronic organ damage were significantly related to QoL. In conclusion, a reduced QoL was mainly determined by pain rate, occupation and educational level. Chronic organ damage, although a major factor determining life expectancy in SCD, was not a determinant of QoL.

Sickle cell disease (SCD) is a hereditary hemoglobinopathy characterized by recurrent microvascular vaso-occlusion and chronic hemolytic anemia resulting in progressive organ damage and reduced life expectancy. [1;2] Given the chronic nature of SCD and the severity of its complications, patients are likely to have a significantly reduced quality of life (QoL). Intuitively and historically, pain is widely regarded as the major factor in determining QoL in SCD. However, even though previous studies have indeed demonstrated a reduced QoL of sickle cell patients, this was often not or not only attributable to pain. [2] Factors such as anxiety, depression and socioeconomic circumstances may also contribute to the reduced QoL of sickle cell patients. [3-5]

Sickle cell patients develop organ damage irrespective of their frequency of acute painful events which has been related to significant morbidity and increased mortality and it seems likely that SCD related organ damage negatively impacts QoL of sickle cell patients. [6] However, to our knowledge, the impact of chronic organ damage on QoL in SCD has not been previously assessed. Therefore, we prospectively assessed the QoL in a cohort of consecutive sickle cell patients in whom chronic organ damage, pain rate and the history of sickle cell related complications in the last five years was systematically analyzed. In addition, the impact of occupation and educational level on QoL of these patients was studied. 
117 adult patients with sickle cell disease ( $\mathrm{HbSS}, \mathrm{HbS} \beta^{0,} \mathrm{HBSC}, \mathrm{HbS} \beta^{+}$) were eligible for our study. Twenty-three patients were excluded from analysis because they were not able to fill in the SF-36 questionnaire for different reasons (illiterate persons, mental retardation or repeated no show at their appointments). These excluded patients did not differ from the study population concerning outcome variables (pain, disease severity, education and occupation). QoL was assessed in 51 patients with $\mathrm{HbSS}, 5$ with $\mathrm{HbS \beta}^{0}, 11$ with $\mathrm{HbS}^{+}$and 27 patients with HbSC.

The QoL data of our population are presented in table I. As expected, our patient group scored lower on QoL compared to the healthy Dutch population [9] (data not shown). No correlation between the MCS and PCS was found in the sickle cell population (spearman $\mathrm{r}=0.14 ; \mathrm{P}>0.20$ ). When comparing male to female sickle cell patients the overall PCS appeared to be significantly higher in males as compared to females $(\mathrm{P}=0.015)$. We found no significant difference in the overall MCS between males and females. Older patients scored lower on the PCS in comparison to younger patients $(\mathrm{P}=0.002)$ while no significant differences in QoL scores between genotypes was found (data not shown).

The QoL scores in relation to pain rate are depicted in table II. With respect to the MCS, the overall score and all subscales, except for mental health, were significantly lower in patients with the highest pain rate $(\mathrm{P}=0.021)$. Although significantly lower scores were found on the role-physical $(\mathrm{RF})$ scale $(\mathrm{P}=0.005)$ and the general health $(\mathrm{GH})$ scale $(\mathrm{P}=0.033)$ in patients with the highest pain rate the overall PCS was not determined by the number of admissions for painful crises $(\mathrm{P}=0.110)$. Also analysis by linear regression confirmed that pain rate is significantly associated with MCS and is less likely to influence the PCS (data not shown).

The prevalence of different forms of organ damage in our study population was: PHT: $24,5 \%$, renal failure: $3,2 \%$, microalbuminuria: $21,3 \%$, retinopathy: $31,2 \%$, iron overload: 9,6\%, avascular osteonecrosis: $11,7 \%$ leg ulcers: $6,4 \%$, ACS: $25,5 \%$, priapism: $8,5 \%$ and stroke: 4,3\%. Except from lower QoL scores (for the PCS) in patients with iron overload $(\mathrm{p}=0.017)$, no association between any form of organ damage or sickle cell related complications and QoL scores was found (table III). Moreover, when patients with organ damage and complication were divided according the pathogenesis (hemolysis related complication versus vaso-occlusion/ischemia related complications) no significant differences in QoL was observed as compared to the patients without organ damage at all.

With respect to the relation between occupation and educational level and QoL scores, the PCS was strongly associated with occupation and level of education $(p<0.001)$. The 
69 overall MCS was not related to occupation or the level of education (respectively $\mathrm{p}=0.206$ and $70 \mathrm{p}=0.177)$. Occupation and the level of education were not different between different genotypes and were not related to pain rates.

Sickle cell disease (SCD) is heterogeneous in its clinical presentation with patients 73 being continuously admitted for the management of disease related complications at one end 74 of the spectrum, and patients rarely requiring medical care at the other. [6] Irrespective of the 75 frequency of acute clinical complications, most patients develop accumulating organ damage 76 throughout their lives as result of chronic hemolytic anemia and ongoing vaso-occlusion. [1] With respect to QoL, previous studies have reported that sickle cell patients have lower QoL scores as compared to race and age matched controls which were related to pain. [18-20] However, its relation to the presence of chronic organ damage has not been described before. In the present study organ damage appeared not to be related to any of the QoL scores. If patients were grouped according the pathophysiology of their different forms of organ damage or a history of sickle cell related complication as recently proposed by Kato et al., also no relation with QoL scores was demonstrated. [15] Surprisingly, PHT, which has been related to early mortality in SCD, was not related to QoL in our patients. This might be explained by the fact that our study population consists of patients with mild PHT (regurgitation jet flow velocity $<2.9 \mathrm{~m} / \mathrm{s}$ ) which is generally not related to severe complaints or significantly reduced exercise tolerance.

Factors significantly associated with a reduced QoL were pain rate and social circumstances defined as educational level and occupation. Interestingly, pain rate was only associated with a reduced MCS while the social circumstances of the patients were related to the PCS. These data suggest that frequent painful and unpredictable crises are an important psychological burden rather than a physical burden to sickle cell patients as has been suggested previously. [21] In contrast, social circumstances as reflected by occupation and level of education were mainly related to the PCS, suggesting that only patients in good physical performance are able to finish school and find jobs independently of the frequency of admission for painful crises. This was further supported by the finding that no correlation between the MCS and PCS was found in the sickle cell population, which is in contrast to the findings of QoL assessments in healthy individuals. [9] Similar to previous findings of McClish et al. we did not find a correlation between genotype and QoL scores. [20] Also no difference in QoL scores was observed between patients on hydroxyurea and those who are not on hydroxyurea. This might be explained by the fact that in our study population hydroxyurea was only prescribed to reduce painful crises and the occurrence of acute chest 
103 syndrome. By reducing these complications in patients with an otherwise more severe clinical 104 presentation, hydroxyurea may have improved the QoL. This is in line with a previous 105 prospective study of Ballas et al. who demonstrated an improved QoL with the use 106 hydroxyurea.[22]

107 Certain limitations of our study should be taken into account. First, by defining pain 108 rate by the amount of clinical admissions, the conclusions of our study may not be 109 extrapolated for the number of painful crises experienced at home which have been reported 110 to occur frequently in sickle cell patients. [23] However, previous studies have shown that 111 pain (during a painful crises as well as chronic pain) is related to QoL in sickle cell patients. $112[18 ; 20 ; 22]$ Second, most forms of organ damage and sickle cell related complications were 113 only present in a relative small group of patients which may have underpowered our study to 114 detect an effect of specific forms of organ damage on QoL. Mild pulmonary hypertension, as 115 one of the most relevant forms of organ damage which has been associated with poor 116 prognosis, was present in $24 \%$ of all sickle cell patients and was not related to QoL.

117 In conclusion, the quality of life scores in consecutive sickle cell patients appear to be 118 determined mainly by pain rate and social circumstances. Despite the contribution of organ 119 damage such as (mild) pulmonary hypertension on prognosis and life expectancy, cumulative 120 organ damage does not seem to be an important determinant of QoL in SCD. In terms of 121 clinical presentation, pain rate is the most important factor for the QoL of adult sickle cell 122 patients.

123 Methods

124 Adult sickle cell patients visiting the Department of Hematology of the Academic 125 Medical Centre (AMC) in Amsterdam were eligible for our study. Inclusion criteria were: 126 high performance liquid chromatography (HPLC) confirmed diagnosis of homozygous sickle 127 cell anemia (HbSS), sickle-C disease ( $\mathrm{HbSC}), \mathrm{HbS} \beta^{+}$-thalassemia $\left(\mathrm{HbS} \beta^{+}\right.$-thal) or $\mathrm{HbS} \beta^{0}$ 128 thalassemia $\left(\mathrm{HbS}^{0}\right.$-thal), age 18 years or older and capable of filling in a questionnaire 129 (Dutch or English). All data were collected during a routine outpatient clinic visit.

130 QoL was assessed by the use of SF-36 forms. The SF-36 is a short-form health survey 131 which has been proven to be valid and reliable in het black population. [7] It has been 132 previously used to determine QoL in adults with SCD. [8] Briefly, it yields eight different 133 scales (physical functioning, role limitations due to physical problems, role limitations due to 134 emotional problems, social functioning, mental health, vitality, bodily pain and general health 135 perceptions) of functional health and well-being as well as psychometrically-based physical 136 and mental health summary measures. The SF-36 is a generic measure, which is not age, 
137 disease or treatment specific. Accordingly, the SF-36 has proven to be useful in surveys of 138 general and specific populations, comparing the relative burden of diseases. [9] All patients were asked to complete this questionnaire during a routine out-patient visit. All scale scores are linearly converted to a 0 to 100 scale, with higher scores indicating higher levels of

141 functioning or well being. We analyzed the scores of our study population and compared the 142 data with the scores of the general healthy Dutch population. [9]

143 Data on social circumstances represented by occupation and level of education were 144 routinely gathered during the first routine visit for every patient. With respect to occupation 145 patients were divided in: employed, unemployed or student. Education level was divided in: 146 high school or less, vocational education/ community college and tertiary education/university. 147 Pain rate was defined as the number of admissions for treatment of a vaso-occlusive 148 crisis from January 2002 until January 2007 and was determined by chart review. [6] 149 Subsequently three groups were arbitrarily defined: patients without, patients with $<1$ 150 admission for painful crises per year and patients with 1 or $>1$ admission for painful crisis 151 per year.

152 Organ damage and sickle cell related complications were assessed by systematic 153 screening and medical record review and defined as follows: Pulmonary hypertension (PHT): 154 tricuspid regurgitation jet flow velocity (TRV) equal to or higher than $2.5 \mathrm{~m} / \mathrm{sec}$ in rest 155 detected by Doppler echocardiography. PHT was considered absent with no or only trace 156 TRV. [10] Renal failure: an estimated creatinine clearance lower than $100 \mathrm{~mL} / \mathrm{min}$ 157 (Cockcroft and Gault). Microalbuminuria: urinary creatinine (mmol/L) to urinary albumin 158 (mg/L) ratio higher than 3.5 for males and higher than 2.5 for females confirmed with 24 159 hours urine collection with microalbuminuria higher than $30 \mathrm{mg} / 24$ hours. [11]Retinopathy: 160 presence of at least mild non-proliferative retinopathy. [12]Iron overload: plasma ferritin 161 level higher than $1000 \mu \mathrm{mol} / \mathrm{L}$ (on at least three occasions during steady state) and a history 162 of more than 20 transfused packed cells. [13] Symptomatic avascular osteonecrosis: local 163 pain and reduced function with documented osteonecrosis of the femoral or humeral head (hip 164 or shoulder X-ray) or a history of surgical intervention for osteonecrosis. Leg ulcers: chronic 165 ulcers of the ankle not otherwise explained. Acute chest syndrome: defined as described by 166 Stuart et al. occurring between January 2002 and January 2007. [14] Priapism: spontaneous 167 painful erection requiring hospital care. Stroke: history of stroke confirmed by magnetic 168 resonance imaging or computerized tomography. We analyzed the relation between organ 169 damage and QoL both for each form of organ damage or complication separate as well as for 170 groups. Groups were divided in a group with no organ damage or sickle cell related 
171 complications, a group with organ damage or complications due to hemolysis (leg ulcers, 172 PHT, priapism and stroke) or a group with organ damage related to vaso-occlusion (ACS, 173 retinopathy, avasculair osteonecrosis, renal failure and microalbiminuria) as proposed 174 previously. [15]

175 Hematological and biochemical laboratory parameters were assessed at the same visit 176 at which the patient completed the QoL questionnaire. Fetal hemoglobin percentage (HbF\%) 177 was determined by cation-exchange high performance liquid chromatography and $\alpha$ 178 thalassemia screening was performed with a multiplex PCR assay. [16] If not available we 179 used the results from the latest outpatient visit. [17]

180 All numbers in the tables are medians with corresponding inter quartile ranges (IQR) 181 unless stated otherwise. Difference in continuous data between groups was tested with the 182 Mann-Whitney test. Difference in categorical data between groups was tested with the Chi183 square test. P-values $\leq 0.05$ were considered statistically significant. Multiple linear regression 184 analyses were performed to analyze the interaction between the different scales of the SF-36 185 questionnaire and pain rate. All missing data were considered missing at random. In the case 186 that one or more questions were not answered in a specific scale of the SF-36 questionnaire, 187 the mean value of the remaining questions on that specific scale was used for the missing 188 items. When half or more of the questions were not answered, the results of the specific scale 189 were discarded. Statistical analysis was performed by using SPSS 12.0.2 (SPSS Inc, Chicago, 190 IL). 


\section{Reference List}

1 Schnog JJ, Lard LR, Rojer RA, van der Dijs FP et al. : New concepts in assessing sickle cell disease severity. Am J Hematol 1998;58:61-66.

2 Serjeant GR: The emerging understanding of sickle cell disease. Br J Haematol 2001;112:3-18.

3 Levenson JL, McClish DK, Dahman BA, Bovbjerg VE, et al.: Depression and anxiety in adults with sickle cell disease: the PiSCES project. Psychosom Med 2008;70:192-196.

4 Anie KA: Psychological complications in sickle cell disease. Br J Haematol 2005;129:723-729.

5 Palermo TM, Riley CA, Mitchell BA: Daily Functioning and Quality of Life in Children With Sickle Cell Disease Pain: Relationship With Family and Neighborhood Socioeconomic Distress. J Pain 2008.

6 van Beers EJ, van Tuijn CF, Mac Gillavry MR, van der GA, et al.: Sickle cell disease-related organ damage occurs irrespective of pain rate: implications for clinical practice. Haematologica 2008;93:757-760.

7 McHorney CA, Ware JE, Jr., Lu JF, Sherbourne CD: The MOS 36-item ShortForm Health Survey (SF-36): III. Tests of data quality, scaling assumptions, and reliability across diverse patient groups. Med Care 1994;32:40-66.

8 Panepinto JA: Health-related quality of life in sickle cell disease. Pediatr Blood Cancer 2008;51:5-9.

9 Aaronson NK, Muller M, Cohen PD, Essink-Bot ML, et al.: Translation, validation, and norming of the Dutch language version of the SF-36 Health Survey in community and chronic disease populations. J Clin Epidemiol 1998;51:1055-1068.

10 Gladwin MT, Sachdev V, Jison ML, Shizukuda Y, et al.: Pulmonary hypertension as a risk factor for death in patients with sickle cell disease. $\mathrm{N}$ Engl J Med 2004;350:886-895.

11 Bakker AJ: Detection of microalbuminuria. Receiver operating characteristic curve analysis favors albumin-to-creatinine ratio over albumin concentration. Diabetes Care 1999;22:307-313.

12 Wilkinson CP, Ferris FL, Klein RE, Lee PP, et al.: Proposed international clinical diabetic retinopathy and diabetic macular edema disease severity scales. Ophthalmology 2003;110:1677-1682.

13 Files B, Brambilla D, Kutlar A, Miller S, et al.: Longitudinal changes in ferritin during chronic transfusion: a report from the Stroke Prevention Trial in Sickle Cell Anemia (STOP). J Pediatr Hematol Oncol 2002;24:284-290. 
14 Stuart MJ, Setty BN: Sickle cell acute chest syndrome: pathogenesis and rationale for treatment. Blood 1999;94:1555-1560.

Kato GJ, Gladwin MT, Steinberg MH: Deconstructing sickle cell disease: reappraisal of the role of hemolysis in the development of clinical subphenotypes. Blood Rev 2007;21:37-47.

16 Tan AS, Quah TC, Low PS, Chong SS: A rapid and reliable 7-deletion multiplex polymerase chain reaction assay for alpha-thalassemia. Blood 2001;98:250251.

17 Ou CN, Rognerud CL: Rapid analysis of hemoglobin variants by cationexchange HPLC. Clin Chem 1993;39:820-824.

18 Anie KA, Steptoe A, Bevan DH: Sickle cell disease: Pain, coping and quality of life in a study of adults in the UK. Br J Health Psychol 2002;7:331-344.

19 Thomas VJ, Taylor LM: The psychosocial experience of people with sickle cell disease and its impact on quality of life: Qualitative findings from focus groups. Br J Health Psychol 2002;7:345-363.

20 McClish DK, Penberthy LT, Bovbjerg VE, Roberts JD, et al.: Health related quality of life in sickle cell patients: the PiSCES project. Health Qual Life Outcomes 2005;3:50.

21 Booker MJ, Blethyn KL, Wright CJ, Greenfield SM: Pain management in sickle cell disease. Chronic Illn 2006;2:39-50.

22 Ballas SK, Barton FB, Waclawiw MA, Swerdlow P, et al.: Hydroxyurea and sickle cell anemia: effect on quality of life. Health Qual Life Outcomes 2006;4:59.

23 Smith WR, Penberthy LT, Bovbjerg VE, McClish DK et al.: Daily assessment of pain in adults with sickle cell disease. Ann Intern Med 2008;148:94-101. 
Table I. QoL scores of sickle cell patients

\begin{tabular}{llll}
\hline & Male & Female & \\
\hline & SCD & SCD & P* \\
& N=32 & N=61 & \\
\hline PCS & $42.5(10.9)$ & $36.9(11.9)$ & 0.000 \\
Physical Function & $72.5(24.2)$ & $57.4(28.0)$ & 0.000 \\
Role-Physical & $54.8(43.5)$ & $43.8(43.6)$ & 0.000 \\
Bodily Pain & $60.8(27.4)$ & $50.5(28.5)$ & 0.000 \\
General Health & $48.3(23.3)$ & $41.0(23.1)$ & 0.000 \\
& & & \\
MCS & $48.4(12.6)$ & $43.9(12.1)$ & 0.023 \\
Vitality & $59.5(20.8)$ & $45.4(19.3)$ & 0.000 \\
Social Function & $73.8(25.3)$ & $62.7(28.4)$ & 0.000 \\
Role-Emotional & $70.0(41.4)$ & $57.2(45.1)$ & 0.035 \\
Mental Health & $74.0(21.3)$ & $63.6(21.3)$ & 0.000 \\
\hline
\end{tabular}

$$
\text { Mean (SD) }
$$

* Mann-Whitney-test 
Table II. QoL in relation to pain rate

\begin{tabular}{|c|c|c|c|c|}
\hline & $\begin{array}{l}\text { None } \\
(n=25)\end{array}$ & $\begin{array}{l}>0<1 \\
(n=48)\end{array}$ & $\begin{array}{l}>=1 \\
(n=21)\end{array}$ & P* \\
\hline$\overline{\mathrm{PCS}}$ & $45.3(34.4-52.1)$ & $39.6(29.5-49.3)$ & $33.4(28.8-39.2)$ & 0.110 \\
\hline Physical Function & $70.0(35.0-90.0)$ & $70.0(45.0-90.0)$ & $60.0(39.7-75.0)$ & 0.390 \\
\hline Role-Physical & $87.5(0.0-100.0)$ & $50.0(0.0-100.0)$ & $0.00(0.00-50.0)$ & 0.005 \\
\hline Bodily Pain & $62.0(36.5-92.0)$ & $52.0(32.0-80.0)$ & $41.0(26.5-61.0)$ & 0.102 \\
\hline General Health & $52.0(30.0-83.3)$ & $37.0(25.0-57.0)$ & $39.5(21.3-47.0)$ & 0.033 \\
\hline MCS & $50.6(39.3-57.6)$ & $50.8(38.3-57.1)$ & $36.7(30.4-48.2)$ & 0.021 \\
\hline Vitality & $55.0(37.5-75.0)$ & $50.0(43.8-65.4)$ & $40.0(31.3-48.8)$ & 0.022 \\
\hline Social Function & $75.0(56.3-100.0)$ & $75.0(50.0-100.0)$ & $50.0(37.5-75.0)$ & 0.003 \\
\hline Role-Emotional & $100.0(8.3-100.0)$ & $100.0(33.3-100.0)$ & $0.00(0.00-100.0)$ & 0.032 \\
\hline Mental Health & $80.0(46.0-92.0)$ & $72.0(48.0-89.0)$ & $56.0(52.0-68.0)$ & 0.319 \\
\hline
\end{tabular}

\section{Median (IQR)}

*Kruskal Wallis Test 
Table III. QoL in relation to organ damage and sickle cell related complications.

\begin{tabular}{|c|c|c|c|c|c|c|c|}
\hline \multirow[b]{2}{*}{ Manifestations } & \multirow[b]{2}{*}{$\mathrm{N}$} & \multicolumn{2}{|c|}{ PCS } & \multirow[t]{2}{*}{ P* } & \multicolumn{2}{|c|}{ MCS } & \multirow[t]{2}{*}{ P* } \\
\hline & & Present & Absent & & Present & Absent & \\
\hline Pulmonary hypertension & 23 & $39.8(11.3)$ & $38.5(11.6)$ & 0.701 & $50.2(10.3)$ & $44.3(12.8)$ & 0.060 \\
\hline Renal failure & 3 & $28.4(14.4)$ & $39.0(11.4)$ & 0.132 & $50.3(11.1)$ & $45.2(12.4)$ & 0.466 \\
\hline Microalbuminury & 20 & $34.9(10.5)$ & $39.9(11.9)$ & 0.106 & $41.6(13.6)$ & $46.6(12.3)$ & 0.186 \\
\hline Retinopathy & 30 & $37.4(10.6)$ & $38.6(11.9)$ & 0.638 & $47.5(11.6)$ & $45.5(12.4)$ & 0.463 \\
\hline Iron overload & 9 & $30.1(8.3)$ & $39.9(11.8)$ & 0.017 & $41.4(12.4)$ & $45.9(12.4)$ & 0.348 \\
\hline Avascular osteonecrosis & 11 & $36.1(7.7)$ & $39.0(12.1)$ & 0.444 & $39.8(13.8)$ & $46.1(12.0)$ & 0.449 \\
\hline Leg ulcers & 6 & $38.5(11.9)$ & $38.6(11.7)$ & 0.966 & $40.6(7.3)$ & $45.6(12.5)$ & 0.344 \\
\hline Acute chest syndrome & 24 & $35.0(12.9)$ & $40.1(11.2)$ & 0.057 & $46.3(10.6)$ & $45.2(13.0)$ & 0.843 \\
\hline Priapism & 8 & $45.7(7.8)$ & $41.4(11.8)$ & 0.425 & $47.4(11.1)$ & $48.7(13.4)$ & 0.606 \\
\hline Stroke & 4 & $42.2(13.0)$ & $38.7(11.8)$ & 0.190 & 45.7 (16.9) & $45.5(12.3)$ & 0.429 \\
\hline
\end{tabular}

Mean (SD)

* Mann Whitney U Test 